\title{
APHRODITE PHILOMMÊDÊS IN THE THEOGONY
}

\author{
ELSA BOUCHARD \\ Université de Montréal*
}

\begin{abstract}
Discussion of Aphrodite's epithet philommeidês/philommêdês in Hesiod Theogony 200. Hesiod's aetiological account of this name suggests the meaning 'wiles-loving' as well as 'genitals-loving'. This interpretation is supported by a number of episodes from Archaic poetry in which literary or mythical figures make use of a ruse to permit the fulfilment of their erotic longing, or conversely exploit someone else's desire as a means to achieve supremacy in a power struggle.
\end{abstract}

Keywords: Hesiod, Aphrodite, philommêdês, etymology

In his account of the birth of Aphrodite Hesiod gives the goddess no less than four names, each of which is provided with an ad hoc etymology consistent with the mythical context:

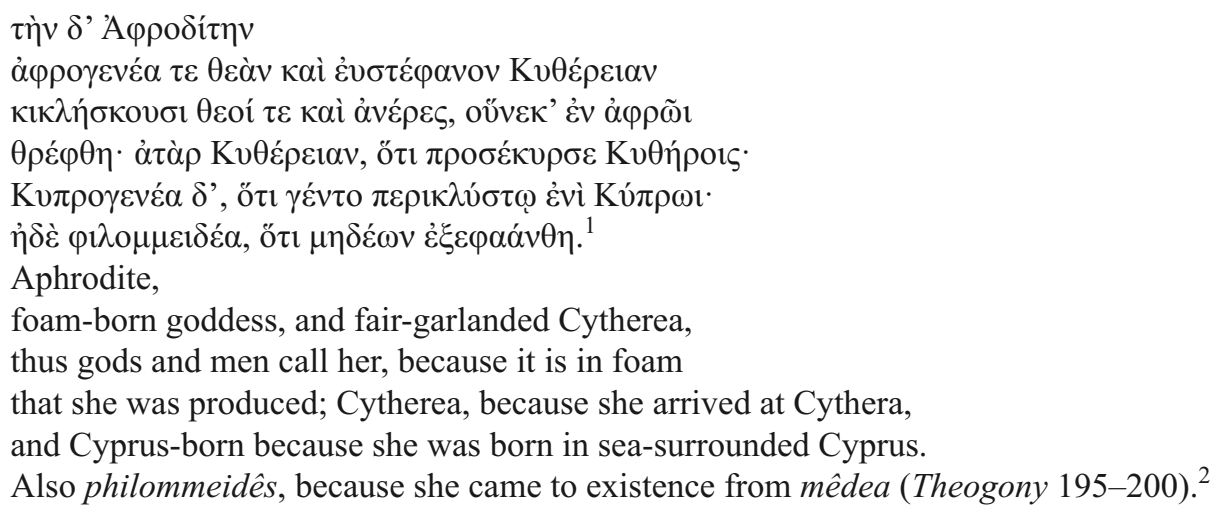

I call these etymologies and not simply wordplays because the passage contains an explicit

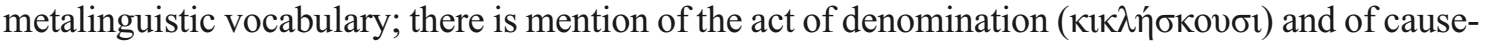

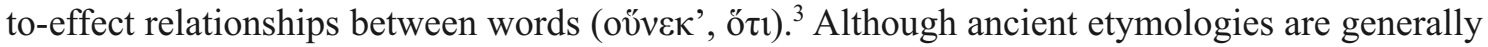
held to be 'scientifically' (that is, linguistically) worthless, they provide us with precious clues as to the ideas that their authors entertained of their own divinities - whatever other 'correct' accounts of the origins of Greek gods may be proposed by historians of religion. ${ }^{4}$ While possessing genuine literary appeal and giving poets occasions to show off their wit and inventiveness, ${ }^{5}$ they also reveal an authentic concern with issues such as the heuristic value of language and the effectuality of divine names. In fact, Hesiodic poetry is packed with names and epithets, many of which are

* elsa.bouchard@umontreal.ca.

1 Edited by West (1966), who brackets v. 196. The repetitiveness of these lines has created suspicion of interpolation; see Arnould (2009) 4-6 for a review of the critical tradition.

2 All translations are my own. I leave the words $\varphi 1 \lambda \circ \mu \mu \varepsilon 1 \delta \varepsilon \dot{\varepsilon} \alpha$ and $\mu \eta \delta \varepsilon \dot{\varepsilon} \omega v$ untranslated, as their complex meaning is the very topic of this paper.

${ }^{3}$ Gambarara (1984) 106 identifies these elements as criteria distinguishing etymology from wordplay.

${ }^{4}$ Cf. Pironti (2005) 129-30. The debates on
Aphrodite's place in the Greek pantheon have long been monopolized by the question of her origins: $c f$. PirenneDelforge (1994) 1-6. She is now generally believed to be related to Oriental Astarte: Dugand (1974); Burkert (1985) 152; West (2000); contra Boedeker (1974). According to Heubeck (1965), followed by Burkert (1985) 154-55, the word $\varphi 1 \lambda \circ \mu \mu \eta \delta$ '́ means 'possessing male genitals' and is to be explained by a Semitic androgynous ancestor of the Greek goddess.

${ }^{5}$ Hesiod himself may be thought to be more playful than the label 'didactic poet' suggests: see Heath (1985). 
accompanied by (more or less) explicit epexegetical comments. ${ }^{6}$ This is obviously true of the Theogony, but Works and Days also contains its share of etymologies, especially in the first (mythical) quarter of the poem: for instance Zeus, who the Muses are asked to sing, is 'he by whom

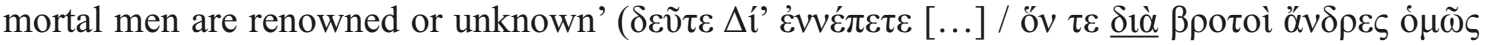

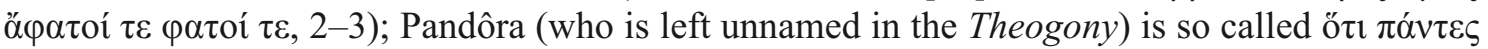

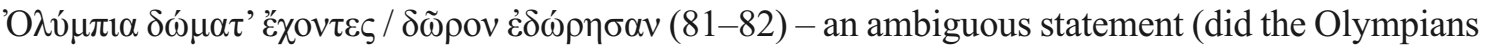
give presents to her or did they give her as a present - to humankind?). Both explanations are compatible with the story told by Hesiod, so perhaps the lines are purposely equivocal. I shall argue that the poet exploits such an ambiguity in the passage describing Aphrodite's birth.

Hesiod's glosses of her first three appellations are fairly straightforward: Aphrodite from aphros, Cytherea from Cythera, Cyprogenês from Cyprus. ${ }^{7}$ By contrast, line 200 provides an unexpected justification of a common name and contains a striking pun with multiple layers of significance. As it happens, previous attempts to elucidate philommeidês ${ }^{8}$ have imperfectly uncovered the allusions conveyed by the epithet in this specific context, as I hope to show in this paper.

The word as it is transmitted in the manuscripts is $\varphi \imath \lambda \circ \mu(\mu) \eta \delta \eta$ s. It appears to be a variation on $\varphi \imath \lambda o \mu(\mu) \varepsilon 1 \delta \delta^{\prime},{ }^{9}$ a traditional epithet for Aphrodite in epic poetry that is usually translated as 'smile-loving' in reference to the goddess' obvious association with the realms of seduction and eroticism. ${ }^{10}$ Hesiod himself, a few lines further on, names smiles in the list of her prerogatives:

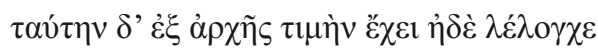

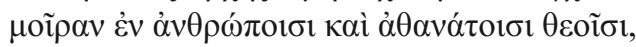

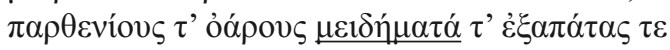

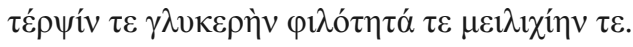

Since the beginning such is her privilege,

the lot she obtained among humans and immortal gods:

maidenly chats, smiles, tricks,

sweet pleasure, lovemaking, ${ }^{11}$ and tenderness (Theogony 203-06).

Considering the frequency of $\varphi 1 \lambda \circ \mu \mu \varepsilon \imath \delta \eta \dot{\varsigma}$ as applied to Aphrodite in epic diction (including Hesiodic poetry), there is no doubt that at line 200 Hesiod is self-consciously substituting $\varphi \imath \lambda о \mu \mu \eta \delta \eta ́ \varsigma, ~ ' g e n i t a l s-l o v i n g '$, for the usual $\varphi \imath \lambda о \mu \mu \varepsilon \imath \delta \eta ́ s$, and grounding this substitution in the

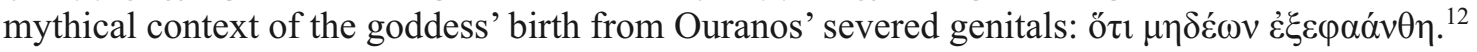

What I want to suggest is that this is not the end of the story. An overwhelming majority of commentators on this passage ${ }^{13}$ have failed to notice that this reinterpretation of $\varphi \imath \lambda o \mu \mu \varepsilon 1 \delta \eta$ $\varsigma$ as

${ }^{6}$ Cf. Deichgräber (1951); Ferrante (1965) 455-61; Duhoux (1967); Duban (1978b); Arnould (2009). Hesiod's etymologies work the other way round from his equally numerous personifications, in which common names and concepts are 'elevated' to a divine, or semi-divine, status.

7 As Clay notes, 'Cytherea' and 'Cyprogenes' are only apparent exceptions to Hesiod's avoidance of local cult epithets, to which he prefers names with a Panhellenic or cosmic tenor: "Hesiod goes out of his way to derive her epithets, "Cyprian" and "Cytherean," from the circumstances of her birth rather than from any specific and local cultic association' (Clay (1988) 326). On Hesiod's Aphrodite and some of her epithets, see, for example, Sale (1961); Leclerc (1978); Morgan (1978); Washbourne (1999); Hansen (2000).

8 See West (1966) 88, 224; Boedeker (1974) 24; Washbourne (1999); Arnould (2009) 4-6.

9 See West (1966) 88 for a discussion of the alterna- tives $\varepsilon / \eta \eta$. The exact word used by Hesiod does not matter much to my argument since ancient etymologies are indifferent to such minor phonological variations. On the 'rules' of ancient etymologizing, see Woodhead (1928); Allen (1948); Gambarara (1989); Lallot (1991); TsitsibakouVasalos (1997); Peraki-Kyriakidou (2002); Sluiter (2015).

10 On the erotic overtones of Aphrodite's smiles, see Boedeker (1974) 23-35; cf. Rosenzweig (2004) 7.

11 For this translation of $\varphi 1 \lambda$ ó $\rceil \zeta$, see Pironti (2007) $38-41$.

$12 C f$. Risch (1947) 76; Washbourne (1999) 136. The sequence of events - Cronos' trick, then Aphrodite's birth - is analysed as a whole by Heubeck (1966).

${ }^{13}$ See the references listed at n.8. Admittedly, many have noticed that the whole episode 's'articule autour du mot mèdéa, qui concerne à la fois les pensées et les parties sexuelles' (Pironti (2005) 130). Duban (1978a)

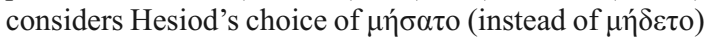


$\varphi \imath \lambda o \mu \mu \eta \delta \eta ́ s$ with its attending aetiological account ('because she was born from $\mu \eta ́ \delta \varepsilon \alpha$ ') also admits the meaning ploy-loving, since Aphrodite is indirectly born from Gaia's and Cronos' ploys ( $\mu \eta \dot{ } \delta \varepsilon \alpha$, an exact homonym to the word meaning 'genitals'). Indeed Ouranos' castration is

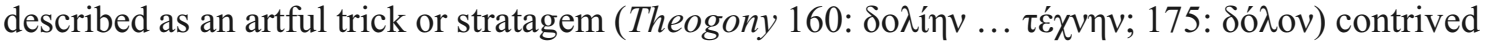
by Gaia and and her crooked-minded, $\alpha \gamma \kappa v \lambda о \mu \eta \dot{\tau} \tau \varsigma$, son. It is thus perfectly legitimate to take the second part of line 200 to mean 'because she was born from ploys'. The ambiguousness of the word $\mu \eta \dot{\delta} \delta \varepsilon \alpha$ in Hesiod (and in epic diction in general) ${ }^{14}$ is clearly illustrated by juxtaposing the following metrically equivalent côla:

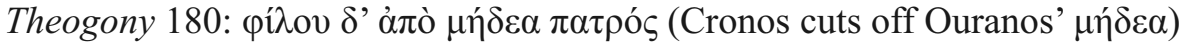

Theogony 398: $\varphi$ í $\mu \eta \dot{\delta} \delta \varepsilon \alpha$

It certainly comes as no surprise that Hesiod should simultaneously ascribe to Aphrodite a fondness for genitals and for trickery. At Theogony 205 he lists $\dot{\xi} \xi \alpha \pi \alpha ́ \tau \alpha$ along with smiles and maid-

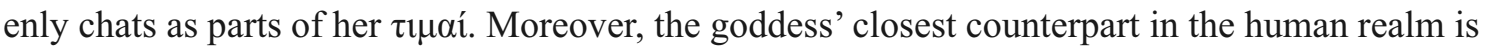
Pandôra, a 'beautiful evil' whose very name evokes the deception ( $\delta$ ó $\lambda \mathrm{o} \varsigma$ ) concealed in this divine

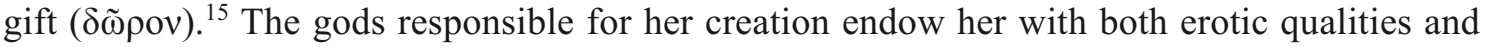

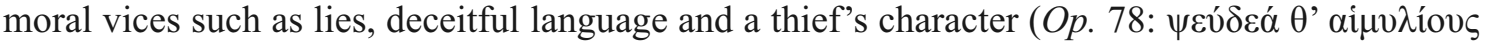
$\tau \varepsilon \lambda$ ó programmatic value in Theogony 200 in addition to its aetiological claim: while Aphrodite's birth is part of the succession myth from Ouranos to Cronos to Zeus, it also introduces a theme that proves to be ubiquitous in Hesiod's poems, namely cunning. The same narrative strategy is used in the nearby passage on the name of the Titans:

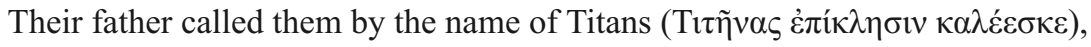
the great Ouranos, in his quarrel with the children that he had begotten.

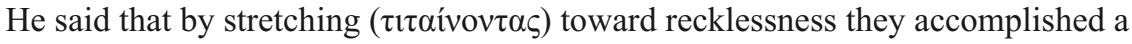

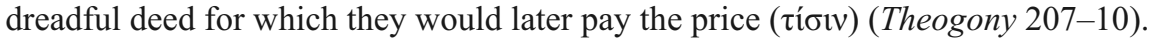

Most commentators perceive a double etymology in this passage, the name Titans being glossed

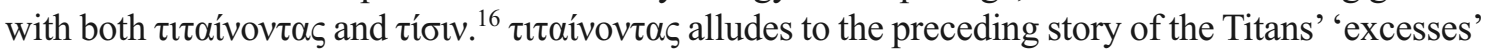

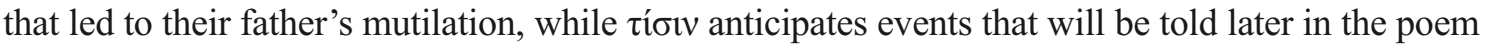
- the chastisement they incur from the Olympian gods who eventually overthrow them. ${ }^{17}$ Likewise, the double significance of $\varphi \imath \lambda o \mu \mu \eta \delta \eta$ ' points both backwards to the theogonical account and forwards to the future state of things, when gods and men are submitted to the suspicious power of Aphrodite. ${ }^{18}$

at Theog. 166 and 172 as a way to avoid the repetition of the morpheme med- at v. 200 ( Arnould (2009) 5-6 signals the existence of a parallelism between Aphrodite's birth from her father's genitals and that of Athena from Zeus' head after he has swallowed Mètis, and she mentions en passant that linguistically there is no good reason not to link $\mu \eta ́ \delta \varepsilon \alpha$ to the root of $\mu \eta ́ \delta o \mu \alpha 1$ (though for the purposes of this paper, linguistic likelihood is only secondarily relevant, as I have stressed earlier). On the parallelism between Aphrodite and Athena in Hesiod, see also Leclerc (1978), who to my knowledge is the only scholar to elaborate to any extent on the double meaning of $\mu \eta \dot{\delta} \delta \alpha$ : (1978) 16-17. Despite the previously cited works, the specific reference to Aphrodite's cunning in $\varphi \imath \lambda o \mu \mu \eta \delta \dot{\zeta} \varsigma$ remains unexplored.

14 According to Nagy (1974) 265-75, this word possesses a thematic unity in Homer and Hesiod, where it denotes a kind of power that is both mental and sexual/reproductive.

15 See Mazur (2004) on the recurrent paronomasia $\delta \tilde{\omega} \rho \mathrm{v} / \delta$ ó $\lambda$ ov around Pandôra. The interpretation of the exact relationship between Aphrodite and Pandôra is a delicate task to handle. It is probably excessive to speak of the latter as the 'incarnation' of the former - as does Marquardt (1982) - and consequently to project onto the goddess all the evils that Hesiod imputes to the first woman and to women in general. On Greek goddesses' strained connection with 'feminity', $c f$. Burkert (1985) 183-84.

16 Risch (1947) 77; Deichgräber (1951) 23; Duban (1978b); Mazur (2004) 243; contra Duhoux (1967), 43 n.31 and passim.

17 See Lauriola (1999), who speaks of 'prolessi narrativa.'

${ }^{18}$ On Aphrodite's influence on the mode of procreation from the primordial states of the cosmos to the generation of the Olympians, see Rudhardt (1986). 
A scholium to the poem shows that the semantic connection might have been made by ancient readers, although the scholiast is mostly intent on giving a moralizing explanation for the homonymy:

$\mu \eta ́ \delta \varepsilon \alpha$ : the genitals ( $\alpha i \delta o i ̃ \alpha)$. The poet does not want us to indulge in sexuality in an irrational fashion

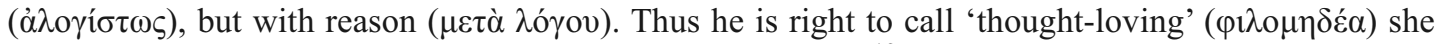
who presides over sexuality (schol. R2WLZX Theogony 188). ${ }^{19}$

Other testimonies suggest a more subtle understanding of the equivocal allusion in Hesiod's $\varphi \imath \lambda o \mu \mu \eta \delta \eta \dot{\zeta}$. One is a poem from the Theognidea:

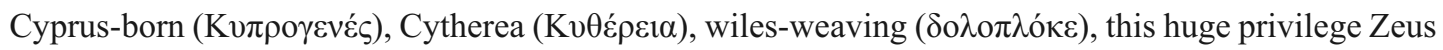

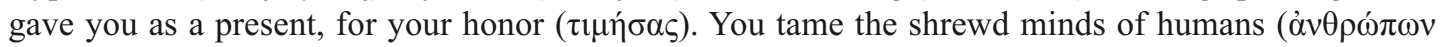
$\pi$

Following a convention of hymnic literature, the poem begins with a series of epithets, the first two of which also feature in the Hesiodic passage under review. But the triad in Theognis is

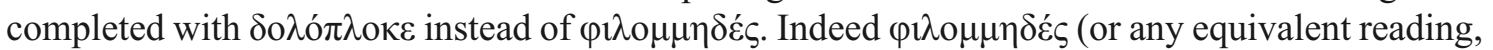
such as $\varphi \imath \lambda \mathrm{o} \mu \varepsilon 1 \delta \varepsilon \dot{\varepsilon} \zeta$ ) would have been unmetrical, but the substitution still appears significant. I shall come back later to the specific resonances of $\delta$ o $\lambda$ ó $\pi \lambda$ oкo $\varsigma$ and the relevance to our problem of the $\Delta$ iò $\varsigma \dot{\alpha} \pi \alpha \dot{\alpha} \eta$, to which the Theognidean poem seems related.

The Orphic Hymn to Aphrodite, of which I give the first three lines, is constituted by a lengthy accumulation of epithets for the goddess:

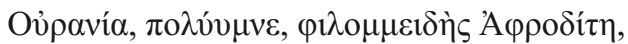

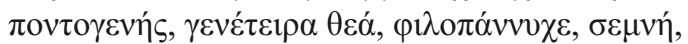

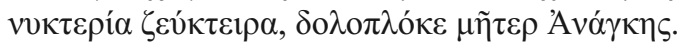

Heavenly, much-celebrated, philommeidês Aphrodite,

sea-born, goddess of generation, lover of nocturnal feasts, venerable,

nightly yoker, wiles-weaving mother of necessity (Orphic Hymns 55.1-3).

Although this text is of late composition, it demonstrates obvious intertextual links with Hesiod: there is a reference to Ouranos and to a birth in the sea, in contrast with the Homeric version that makes Aphrodite a daughter of Zeus and Dionê. Moreover, these lines confirm the goddess' special alliance with night ( story of Ouranos' castration and Aphrodite's creation is immediately followed by the four lines on the name of the Titans and then by the extensive enumeration of the progeny of Night (211-

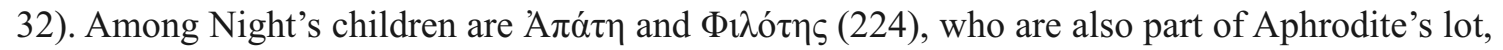
as noted earlier.

This intimate link between Aphrodite and Night might be reflected in some of her cult titles. ${ }^{21}$ She was worshipped as $\mu \varepsilon \lambda \alpha$ uví $\varsigma$ in Thespiai (next to Hesiod's Ascra), Corinth and Melangeia

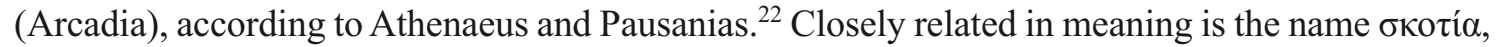
which was used in Cretan Phaistos ${ }^{23}$ and possibly Egypt. ${ }^{24}$ Remarkably, the two entries in the

19 Edited by Di Gregorio (1975).

${ }^{20}$ Cf. Orph. Hymn 3.2, where Night is called Cypris. According to Ramnoux (1986) 228-29, this hymn contains a 'dialectical' theology whose origins lie in the Archaic period.

${ }^{21}$ Cf. Pironti (2007) 81. Gantar (1957) relates $\mu \varepsilon \lambda \alpha \imath$ í $_{\zeta}$ and $\sigma \kappa o \tau i ́ \alpha$ to an Oriental myth in which Ishtar (Aphrodite's Babylonian counterpart) receives a black cloak representing the nocturnal sky - hence also the name Oủpavía.

22 Ath. 13.588c; Paus. 2.2.4, 8.6.5, 9.27.5. Pausanias explains the epithet by the fact that sexual intercourse is more frequent at night (cf. 8.6.5-6).

${ }^{23}$ Cf. Et. Gud. к 352; Et. Mag. 543.48-50.

${ }^{24}$ Hesychius Lexicon $\sigma 1124$. 


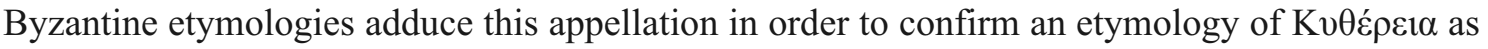

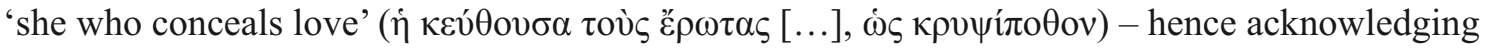
what was likely a common view of Aphrodite's connection to secretive sexuality.

Combined with the violent circumstances of her birth in the Hesiodic account, Aphrodite's complicity with Night highlights the more worrisome side of the goddess; indeed, recent scholarship has convincingly contested her once monolithic image as the 'goddess of love'. ${ }^{25}$ In Archaic poetry, night is a privileged moment for cunning minds to deploy a variety of schemes. A famous example is the nocturnal escapade that costs the life of the suggestively named Dolon in the Iliad, but one need not go beyond Hesiod to confirm this: the very trick concocted against Ouranos was fulfilled during the night. ${ }^{26}$

It is also at nighttime that Hermes accomplishes his glorious theft of Apollo's cows, as is recounted in the Homeric hymn to the former:
Suddenly craving ( $\left.\dot{\varepsilon} \rho \tau \tau^{\prime} \zeta \omega v\right)$ for meat,
he jumped out of the fragrant hall to keep watch,

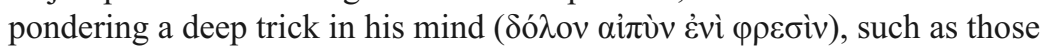
that thieves $(\varphi \imath \lambda \tilde{\eta} \tau \alpha l)$ perform at the hour of black night.
The Sun was sinking below the earth into the Ocean
along with his horses and chariot, when Hermes
arrived at a run at the shady mountains of Pieria,
where the immortal cattle of the blessed gods had their dwelling (64-71).

Instead of Homeric $\lambda \eta \ddot{\sigma} \sigma \tau \eta \dot{\rho}$, the word used for 'thief' here is $\varphi \imath \lambda \eta \dot{\tau}\rceil$ (1.67), and it is again associated with Hermes later in the poem. ${ }^{27}$ In a fragment of Hellanicus this appellation is given a mythological etymology based on its obvious similarity with $\varphi \imath \lambda \varepsilon i v$ :

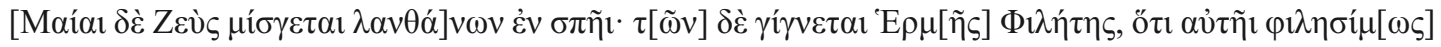
бטvєкоц $\mu[\tilde{\alpha} \tau \mathrm{o}]$.

Zeus had sex with Maia secretly, in a cave. From them was born Hermes [named] $\varphi \imath \lambda \eta \dot{\tau \eta} \varsigma$, because Zeus

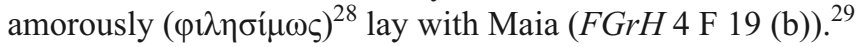

Hermes is in fact a figure closely related to Aphrodite, with whom he shares the quality of cunningness and the status of go-between. ${ }^{30}$ It is telling that in Plato's Cratylus, the name Hermes

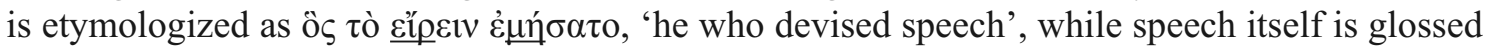
as a power properly belonging to 'the character of an interpreter, a messenger, a thief, a deceiver in words and a merchant'. ${ }^{31}$ The epithet $\varphi \imath \lambda \dot{\eta} \tau \eta_{\varsigma}$ is first attested in Hesiod, albeit not in relation to Hermes:

Do not let a woman who flaunts her buttocks deceive ( $\dot{\varepsilon} \xi \alpha \pi \alpha \tau \alpha \dot{\tau} \omega)$ your mind by cajoling you with guileful words ( $\alpha i \mu v i \lambda \alpha \kappa \omega \tau i ́ \lambda \lambda o v \sigma \alpha)$, while she probes your granary. He who trusts a woman is trusting thieves ( $\varphi \imath \lambda \dot{\eta} \tau \eta 1 \sigma v)(O p .373-75)$.

25 See Pironti (2010), who emphasizes her close connection to the realm of war. In this regard, Aphrodite appears to transcend her traditional opposition to Athena.

26 Theogony 176.

27 Homeric Hymn to Hermes 159, 175, 214, 292, 446.

28 As Thomas (2007) argues, it is preferable to read $\varphi \bar{\imath} \lambda \eta \sigma i ́ \mu \omega \varsigma$ rather than $\varphi \bar{i} \lambda \eta \sigma i ́ \mu \omega \varsigma$. Thomas believes that this text of Hellanicus is based on Hesiod's Catalogue of Women.

\footnotetext{
29 Ancient etymologies of proper names often refer to the parents of the character whose name is being etymologized: Sulzberger (1926); Perdicoyianni-Paleologou (2001).

${ }^{30}$ Friedrich (1978) 90.

31 P1. Crat. 407e6-408b1. Cf. Clay (1989) 106: 'Speech ... belongs to Hermes' domain. But the rhetoric of Hermes is of a peculiar sort; persuasive, seductive, and deceptive, it is characteristically ambiguous and riddling'.
} 
A scholium to v. $375^{32}$ glosses $\varphi \imath \lambda \eta ́ \tau \eta ı เ v$ with $\left.\kappa \lambda \dot{\varepsilon} \pi \tau \alpha \iota \varsigma, \lambda \eta\right\rceil \sigma \tau \alpha i \varsigma \varsigma$ and interprets the lemma

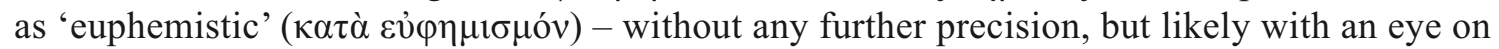
the positive connotations of the $\varphi 1 \lambda$ - root. For my part, I would not exclude the possibility that

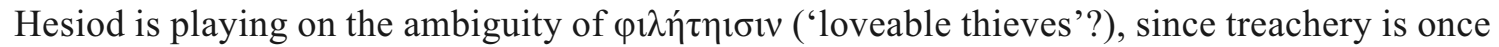
again expressed in terms of threatening seduction. Here as in the Works and Days generally, Hesiod describes realities that are specific to human life and for which there are no real counterparts in the divine world of the Theogony. His disparagement of human sexuality is tightly linked to his well-known mistrust of women, to whom this and similar passages impute the vices of laziness, gluttony and duplicity. By contrast, in the Theogony and in other Archaic accounts, Aphrodite and erôs are conceptualized as cosmic forces of constraint that go largely ungendered. ${ }^{33}$

To come back to the names of Aphrodite: in Archaic and Classical literature many of her

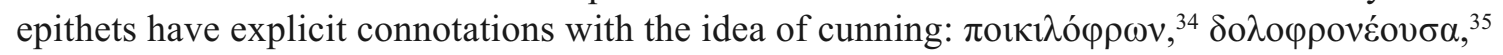

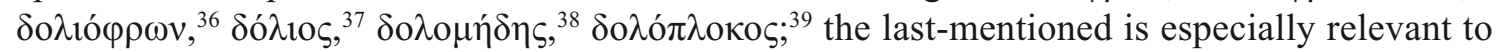
the notion of erotic guile, since it evokes the paradigmatic figure of Penelope weaving at her loom to deceive her suitors. ${ }^{40}$ The goddess has a place among M. Detienne and J.-P. Vernant's 'figures de la ruse', ${ }^{41}$ and indeed she regularly plays a role in stories of deception involving an element of eroticism. The most famous is the Iliadic $\Delta$ iò $\varsigma \dot{\alpha} \pi \alpha ́ \tau \eta$, where Hera uses a blend of physical charm, romantic rhetoric and enchanted devices to seduce her husband - for the sole purpose of distracting him from the battlefield while the Greeks take the upper hand. On this occasion, Hera, who borrows Aphrodite's magic girdle, is also endowed with strongly aphroditic

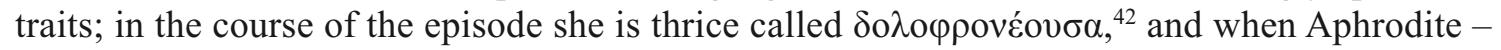
herself falling victim to Hera's lies - agrees to help her, Hera flashes an emphatic smile: 'Thus spoke Aphrodite, and large-eyed, royal Hera smiled ( $\mu \varepsilon i ́ \delta \eta \sigma \varepsilon v)$; smiling $(\mu \varepsilon 1 \delta \eta ́ \sigma \alpha \sigma \alpha)$, she dropped the girdle in her bosom' (Il. 14.222-23). Despite the frequent erotic connotations of smiles, it is obvious that this one is not motivated by Hera's desire to seduce as much as by her triumph at having pulled off a successful trick. ${ }^{43}$ Aphrodite's girdle itself is described as

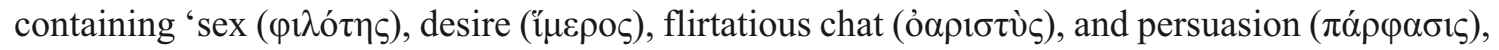

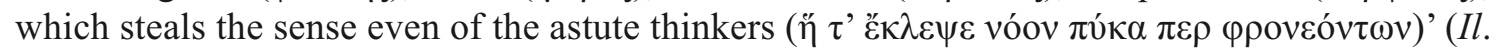
14.216-17). ${ }^{44}$ The $\pi \alpha ́ \rho \varphi \alpha \sigma \varsigma \varsigma$ in particular emphasizes the discursive nature of erotic guile, which is also evinced in Aphrodite's nickname Peithô. ${ }^{45}$ Speech's power to deceive, especially in an erotic context, is also implied in Hesiod's derogatory 'maidenly chats' (Theogony 205) and 'wily coaxing' (Op. 374).

32 Schol. Op. 375b (ed. Pertusi (1955)).

33 I owe this important precision to an anonymous reader for $J H S$, who pointed out to me the inadequacy of the association between 'cunning' and 'female' as regards the Greek cultural representation of the workings of desire. On the different perspectives of the Theogony and the Works and Days on erôs, see Most (2013) especially 173-74.

${ }^{34}$ Sappho $f r$. 1.1. There is an alternate reading, $\pi$ oikt$\lambda$ ó $\theta \rho \omega v$, a lectio difficilior which has been recently defended by Jouanna (1999); but for cogent arguments in favour of $\pi$ oเкı $\lambda$ ó $\rho \omega v$, see Neuberger-Donath (1969).

35 Il. 3.405.

36 Eur. IA 1300.

37 Bacch. Dith. 3.116

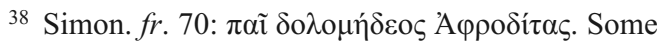
editors read $\delta \circ \lambda o ́ \mu \eta \delta \varepsilon \varsigma$, in which case the epithet modifies Erôs, Aphrodite's son.
39 Sappho fr. 1; Theognis 2.1386; Simon. fr. 36; Lyr. Adesp. fr. 31 Page.

${ }^{40} C f$. Thomas (1999) 4, n.7. On Penelope's cunning, see Marquardt (1985); Winkler (1990) 145-61, who shows that one of the lessons given by the poet of the Odyssey is that 'mêtis is not sex-specific' (160). On the connections between weaving, deception and drugs, see again Winkler (1990) 172-73.

${ }^{41}$ Detienne and Vernant (1974) 269-70; cf. Detienne (2006) 130-33.

${ }^{42} \mathrm{Il} .14 .197,300,329$; once more in the story of Heracles' birth, where Hera deceives her husband by making him swear a treacherous oath (Il. 19.106).

${ }^{43}$ Cf. Levine (1982) 101.

44 On the resemblances between this passage of the $\Delta$ iò $\zeta \dot{\alpha} \pi \alpha \dot{\alpha} \eta$ and Hesiod's description of Aphrodite in the Theogony, see Sale (1961) 510-11; Boedeker (1974) 34.

${ }^{45}$ Buxton (1982). 
Aphrodite also often acts as procuress between mortal lovers. Thus Hippomenes, seeking the hand of Atalanta, owes his success to the goddess who provides him with the apples with which he tricks the maiden into losing the race. ${ }^{46}$ But she especially rejoices in the production of unnatural, heterogeneous couples: in the longest Homeric Hymn to Aphrodite, she admits to having

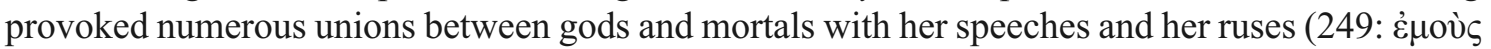

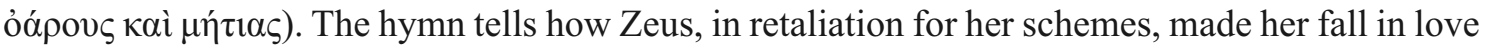
with the mortal Anchises, for whom she indeed admits to 'having lost [her] mind' (253-54: áx́ $\theta \eta v$ $\ldots \dot{\alpha} \pi \varepsilon \pi \lambda \alpha \dot{\alpha} \gamma \chi \theta \eta \nu \delta \dot{\varepsilon}$ vóo1o). ${ }^{47}$ Dressed as a mortal woman and adducing a mendacious story, she manages to bring him to bed with her. Just as in the $\Delta$ iò $\dot{\alpha} \pi \alpha ́ \tau \eta$, this is an example of eroticism being used as a means rather than an end:48 Zeus wants to punish the goddess for her previous exploits by giving her a taste of her own medicine. Thus he secures his authority over the other gods and, by putting an end to the production of semi-divine offspring, he establishes the permanent state of things in the realm of generation. ${ }^{49}$ Aphrodite's lesson is also a show of force on the part of the recently crowned king of heaven. The humiliation she suffers in this episode is quite exceptional in contemporary literature. It finds its closest match in the story of the Phaeacian bard Demodocus reporting her love-affair with Ares, ${ }^{50}$ the outcome of which is the exhibition before other male Olympian gods of the bound adulterous lovers caught in flagrante. But in this case it is a cuckolded husband who takes on the role of the trickster: deprived as he is of any ambition to achieve supremacy in the field of erotics, the lame Hephaestus is reduced to gaining partial compensation for his sexual mortification in the contrivance of a dolos (cf. Od. 8.276) which simultaneously foregrounds his prowess in his own specific sphere (metallurgy) and confronts his adversaries with some shameful consequences of their erotic feat.

Hephaestus' revenge exemplifies a folkloric motif - that of the success of a lesser rival over a greater - which more frequently casts the masterful seducer in the position of the unexpected winner. That is the case in the story of the judgment of Paris, which was told in the cyclic Cypria. ${ }^{51}$ Aphrodite starts off at a disadvantage in the beauty contest: her rivals appear prima facie stronger - one in virtue of her warlike qualities, the other because of her royal status. Yet it is Aphrodite whom Euripides calls $\delta o \lambda$ tó $\varphi \rho \omega v$ in his account of the episode ${ }^{52}$ - who wins, thanks to the lust for Helen that she has breathed into Paris; Aphrodite seduces Paris with the promise of a further seduction. ${ }^{53}$ In this critical moment of the epic saga, erotic passion is created from a thoroughly designed scheme, providing the goddess with $\tau \iota \mu$ in an agonistic situation. Mythical illustrations of this pattern could be multiplied. ${ }^{54}$

A quick comparison of these examples reveals that the conceptual association between eroticism and cunning in Archaic literature can be understood as two-fold. On the one hand, ruse appears in numerous narratives as a favoured means for various types of wooers keen to satisfy their erotic longings. The frequent mythical use of doloi in erotic contexts is probably what Pausanias has in mind when he comments on the accuracy of a cult-title for Aphrodite used by the citizens of Megalopolis:

46 The story is found in fragmentary form in Hesiod,

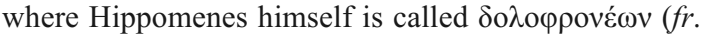
$76 \mathrm{M}-\mathrm{W})$.

47 Some ancient etymologies of the name 'Aphrodite' refer to the folly ( $\alpha \varphi \rho \circ \sigma u ́ v \eta)$ that affects the goddess' victims. These etymologies are either explicit (for example Eur. Trojan Women 990) or implicit (see Tsitsibakou-Vasalos (2003) on Homer and the hymns).

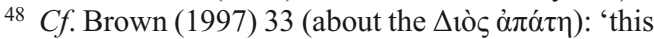
episode is not just about sex: it shows us how sexuality can be exploited to attain other ends'. Brown's article focuses on the linkage of sexual and economic concerns in early poetry - an important aspect of the 'political' tenor of erôs.
49 Cf. Clay (1989) 166; Pirenne-Delforge (1989).

50 Od. 8.266-366.

51 Clay (1989) 156-57 makes the interesting suggestion that the poem's title derives from Aphrodite's central role in the events that launch the story.

52 Iph. Aul. 1299-308.

53 Cf. Clay's definition of seduction as the "conquest of the stronger by the weaker' (Clay (1989) 159), which can be easily extended to include the conquest of a third party by the weaker to the detriment of the stronger, as in the judgment of Paris.

${ }^{54}$ Cf. Apollod. 3.14.4, where Aphrodite punishes Smyrna's negligence of her cult by making her infatuated with her own father. 


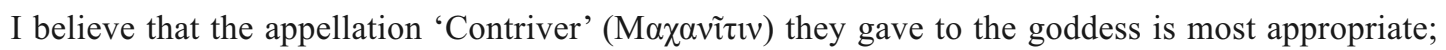
indeed, because of Aphrodite and her works, numerous are the contrivances of men, and diverse their

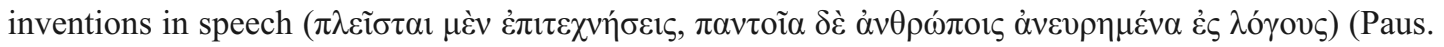
8.31.6-7).

Indeed, Aphrodite's seduction of Anchises rests as much on her deceptive tale as on her physical attractiveness, but sometimes her 'contrivances' take the form of bluntly concrete objects: Atalanta is tricked by apples and Persephone by an enchanted flower. At the beginning of the Homeric Hymn to Demeter, the latter's daughter inadvertedly causes the earth to open for Hades to spring out by plucking 'a narcissus that Earth had produced as a snare ( $\delta$ ó $\lambda \circ v)$ for the roseate girl, in accordance with Zeus' plans' (8-9). Although Aphrodite takes no part in the scheme in this version of the myth, ${ }^{55}$ the story in itself is one of a divine union accomplished through (not one, but) two carefully planned stratagems: first the narcissus, then the pomegranate seed by which Hades secures the return of Persephone. The description of the meadow where the girl is gathering flowers abounds with erotic connotations, ${ }^{56}$ and the visual effect of the narcissus, whose supernatural glow $(\theta \alpha v \mu \alpha \sigma \tau o ̀ v ~ \gamma \alpha v o ́ \omega v \tau \alpha)$ 'was an awe-inspiring sight for all immortal

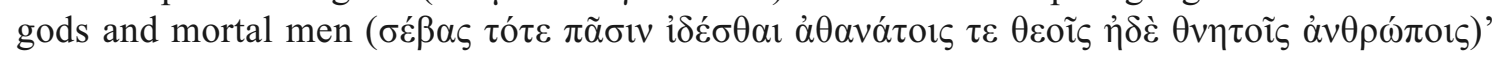
(10-11), evokes Hesiod's account of Zeus' introduction of Pandôra to the world soon after her fabrication:

He led her to the place where the other gods and men were, shining as she was with the adornment of the bright-eyed daughter of a mighty father; and wonder struck immortal gods and mortal men alike

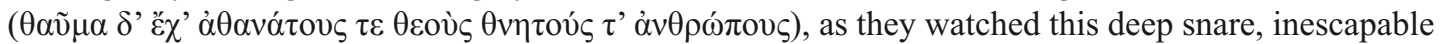

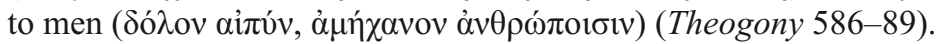

On the other hand, erotic desire is anthropologically conceived of as a strong power susceptible to being instrumentalized with a view to other purposes, such as gaining honour in the context of a power struggle. Such a notion extends beyond the purely mythical and literary realms, since the association between erotic charm, hierarchical relationships and economic success has been noted as a constant feature of the agonistic ideology that lies behind some age-old Greek magical practices. ${ }^{57}$ At times, the two kinds of association can be seen at work simultaneously in a single story, as for instance in that of the Homeric Hymn to Aphrodite: first the goddess is a victim of Zeus' plan to limit her power, but then she herself uses a stratagem to convince the young man to sleep with her. ${ }^{58}$ All these instances suggest that, contrary to what might be the modern assumption, our authors do not perceive an opposition between blind passion and cunning reflection, but rather see them as complementary. ${ }^{59}$ The exact configuration of this counterintuitive psychological notion deserves further investigation.

\footnotetext{
55 She is involved in later versions of the story: see Richardson (1974) 138.

56 Cf. Calame (1996) 213.

57 See Winkler (1990) 77-79; Faraone (1990) 22327 argues that many early mythical elements (such as Aphrodite's girdle in the Iliad, Pandora's necklaces in the Works and Days and Hippomenes' apples) are reminiscences of the Greeks' actual use of love-charms.

58 Cf. Clay (1989) 175.

59 Aristotle seems to endorse a similar conception in a passage contrasting spirit (thumos) with desire (epithumia) (EN 1149b13-18): 'A spirited person does
}

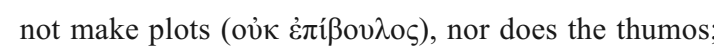
they operate in daylight ( $\varphi \alpha v \varepsilon \rho o ́ \varsigma)$. But desire is like Aphrodite, whom they call "wiles-weaving Cyprog-

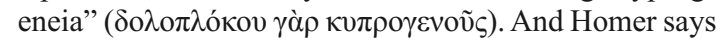
of her embroidered girdle that it contains "Persuasion, which steals the sense even of the astute thinkers" (Il. 14.217)'. This occasional 'enlisting' of ruse in the service of desire should lead one to qualify Calame's characterization of Greek erôs as such a powerful force as to suspend its victim's capacity for understanding and making decisions (cf. Calame (1996) 32). 


\section{Conclusion}

In Archaic thinking, erôs is not so much an emotion as a mode of constraint, and is thus comparable to both force and ruse. As regards Hesiod, who expresses the belief that women and marriage are unavoidable components of life in the Iron Age, we might add 'necessity' as a further point of comparison. ${ }^{60}$ The large intertextual network of coupled references to love and cunning in myth and literature supports the reading of $\varphi 1 \lambda o \mu \mu \eta \delta \eta \dot{s}$ proposed at the beginning of this paper: the epithet acts as a focal point where notions of guile, eroticism and seduction are simultaneously evoked through the homonymy of $\mu \eta \dot{\delta} \varepsilon \alpha$ and the paronomasia with $\mu \varepsilon 1 \delta \eta \mu \alpha \tau \alpha$. Thus I contend that Theogony 200 provides much more than a Volksetymologie, awkwardly interpolated in Hesiod's poem. The Greeks' relationship to language is not confined to technical analysis (although it includes it), but also reveals a reflective engagement with existential stakes: wordplays can have the function of 'controlling unknown forces and unifying diverging impulses' ${ }^{61}$ One could not better describe Hesiod's syncretic tour de force when he makes the philommeidês goddess the encapsulating figure of love and guile. ${ }^{62}$

\section{Bibliography}

Allen, W.S. (1948) 'Ancient ideas on the origin and development of language', TPhS 47, 35-60

Arnould, D. (2009) 'Les noms des dieux dans la Théogonie d'Hésiode : étymologies et jeux de mots', REG $122,1-14$

Boedeker, D.D. (1974) Aphrodite's Entry into Greek Epic (Leiden)

Brown, A.S. (1997) 'Aphrodite and the Pandora complex', CQ 47, 26-47

Burkert, W. (1985) Greek Religion (Cambridge MA)

Buxton, R.G.A. (1982) Persuasion in Greek Tragedy. A Study of Peitho (Cambridge)

Calame, C. (1996) L'Éros dans la Grèce antique (Paris)

Clay, J.S. (1988) 'What the Muses sang: Theogony 1-115', GRBS 29, 323-33

- (1989) The Politics of Olympus. Form and Meaning in the Major Homeric Hymns (Princeton)

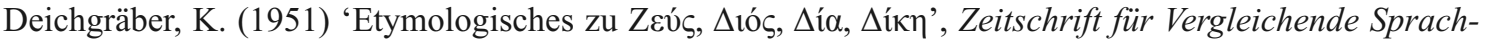
forschung 70, 19-28

Detienne, M. (2006) Les maîtres de vérité dans la Grèce archaïque (Paris)

Detienne, M. and Vernant, J.-P. (1974) Les ruses de l'intelligence. La mètis des Grecs (Paris)

Di Gregorio, L. (1975) Scholia vetera in Hesiodi Theogoniam (Milan)

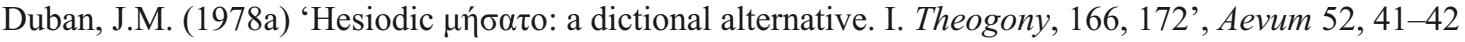

— (1978b) 'Hesiod's Titan etymology reviewed. II. Theogony, 207-210', Aevum 52, 43-44

Dugand, J.E. (1974) 'Aphrodite-Astarté (de l'étymologie du nom d'Aphrodite)', Annales de la Faculté des Lettres et Sciences Humaines de Nice 21, 73-98

Duhoux, Y. (1967) 'Le caractère des Titans. À propos d'une "étymologie" hésiodique', Recherches de philologie et de linguistique 1, 35-46

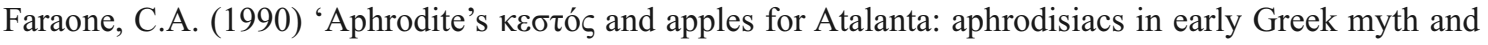
ritual', Phoenix 44, 219-43

Ferrante, D. (1965) 'Immagini etimologiche nei poeti greci dell'età ionico-attica', Rendiconti dell'Istituto Lombardo 99, 453-89

Friedrich, P. (1978) The Meaning of Aphrodite (Chicago)

Gambarara, D. (1984) 'Réflexion religieuse et réflexion linguistique aux origines de la philosophie du langage', in S. Auroux (ed.), Matériaux pour une histoire des théories linguistiques (Lille) 105-14

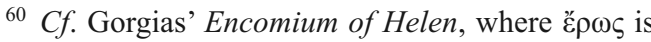

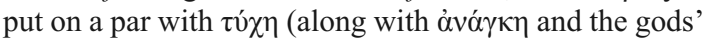
will), Bía and $\lambda$ ó $\gamma o \zeta$ as possible causes of Helen's journey to Troy.

61 Somville (1989) 199 (my translation). On the multiplicity of perspectives allowed by ancient etymologies, $c f$. Wolanin (1995) 515-17.
62 The research behind this article was funded by the Social Sciences and Humanities Research Council of Canada and the Fonds de recherche du Québec. I wish to thank the editor of $J H S$ and the two anonymous referrees for the crucially relevant comments they made on an earlier version of the paper. All remaining blunders and oversights naturally remain my own. 
- (1989) 'L'origine des noms et du langage dans la Grèce ancienne', in S. Auroux (ed.), Histoire des idées linguistiques 1 (Brussels) 79-97

Gantar, К. (1957) 'Поькı $\lambda \dot{\mu} \mu \omega v$ vó $\xi$ ', Živa antika 7, 236-40

Hansen, W. (2000) 'Foam-born Aphrodite and the mythology of transformation', AJPh 121, 1-19

Heath, M. (1985) 'Hesiod's didactic poetry', CQ 35, 245-63

Heubeck, A. (1965) 'Aphroditē Philommēēēs', Beiträge zur Namenforschung 16, 204-06

- (1966) 'Zum Aufbau von Hesiod, Theogonie 161-206', Hermes 94, 233-36

Jouanna, J. (1999) 'Le trône, les fleurs, le char et la puissance d'Aphrodite (Sappho I, v. 1, 11, 19 et 22): remarques sur le texte, sur les composés en - $\theta$ ó́vo et sur les homérismes de Sappho', REG 112, 99126

Lallot, J. (1991) 'ЕТҮМОАОГІА: l'étymologie en Grèce ancienne d'Homère aux grammairiens alexandrins', in J.-P. Chambon and G. Lüdi (eds), Discours étymologiques (Tübingen) 135-48

Lauriola, R. (1999) 'Theog. 207-210: un caso di prolessi narrativa', Athenaeum 87, 15-26

Leclerc, C. (1978) 'Le mythe hésiodique entre le silence et les mots', Revue de l'histoire des religions 194, $3-22$

Levine, D.B. (1982) 'Homeric laughter and the unsmiling suitors', CJ 77, 97-104

Marquardt, P.A. (1982) 'Hesiod's ambiguous view of woman', $C P h$ 77, 283-89

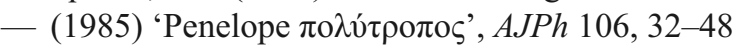

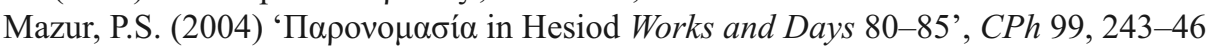

Morgan, G. (1978) 'Aphrodite Cytherea', TAPhA 108, 115-20

Most, G.W. (2013) 'Eros in Hesiod', in E. Sanders, C. Thumiger, C. Carey and N.J. Lowe (eds), Erôs in Ancient Greece (Oxford) 163-74

Nagy, G. (1974) Comparative Studies in Greek and Indic Meter (Cambridge)

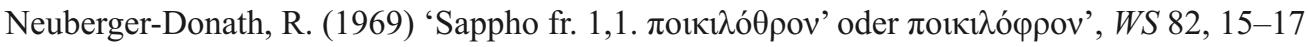

Peraki-Kyriakidou, H. (2002) 'Aspects of ancient etymologizing', CQ 52, 478-93

Perdicoyianni-Paleologou, H. (2001) 'The anthroponymic system of the Greeks and Trojans in Homer', $P P$ $56,328-50$

Pertusi, A. (1955) Scholia vetera in Hesiodi Opera et dies (Milan)

Pirenne-Delforge, V. (1989) 'Conception et manifestations du sacré dans l'Hymne homérique à Aphrodite', Kernos 2, 187-97

- (1994) L'Aphrodite grecque. Contribution à l'étude de ses cultes et de sa personnalité dans le panthéon archä̈que et classique (Athens and Liège)

Pironti, G. (2005) 'Au nom d'Aphrodite: réflexions sur la figure et le nom de la déesse née de l'aphros', in N. Belayche, P. Brulé, G. Freyburger, Y. Lehmann, L. Pernot and F. Prost (eds), Nommer les dieux. Théonymes, épithètes, épiclèses dans l'Antiquité (Turnhout) 129-42

- (2007) Entre ciel et guerre. Figures d'Aphrodite en Grèce ancienne (Liège)

- (2010) 'Rethinking Aphrodite as a goddess at work', in A.C. Smith and S. Pickup (eds), Brill's Companion to Aphrodite (Leiden and Boston) 113-30

Ramnoux, C. (1986) La Nuit et les enfants de la nuit dans la tradition grecque (Paris)

Richardson, N.J. (1974) The Homeric Hymn to Demeter (Oxford)

Risch, E. (1947) 'Namensdeutungen und Worterklärungen bei den ältesten griechischen Dichtern', in Eumusia. Festgabe für E. Howald (Zürich) 72-91

Rosenzweig, R. (2004) Worshipping Aphrodite: Art and Cult in Classical Athens (Ann Arbor)

Rudhardt, J. (1986) Le Rôle d'Éros et d'Aphrodite dans les cosmogonies grecques (Paris)

Sale, W. (1961) 'Aphrodite in the Theogony', TAPhA 92, 508-21

Sluiter, I. (2015) 'Ancient etymology: a tool for thinking', in S. Matthaios and A. Rengakos (eds), Brill's Companion to Ancient Scholarship 2 (Leiden) 896-922

Somville, P. (1989) 'Jeux de mots et sens du sacré dans la religion grecque', Kernos 2, 199-211

Sulzberger, M.R. (1926) 'ONOMA Eח $\Omega N Y M O N$. Les noms propres chez Homère et dans la mythologie grecque', REG 39, 381-447

Thomas, B.M. (1999) 'The rhetoric of prayer in Sappho's "Hymn to Aphrodite”, Helios 26, 3-10

Thomas, O.R.H. (2007) 'Charting the Atlantic with Hesiod and Hellanicus', ZPE 160, 15-23

Tsitsibakou-Vasalos, E. (1997) 'Gradations of science. Modern etymology versus ancient. Nestor: comparisons and contrasts', Glotta 74, 117-32 
- (2003) 'Aphrodite in Homer and the Homeric Hymns: poetic etymology', in C. Nifadopoulos (ed.), Etymologia: Studies in Ancient Etymology (Münster) 119-29

Washbourne, R. (1999) 'Hesiod's smile-loving, member-loving Aphrodite', PP 54, 135-45

West, M.L. (1966) Theogony, Edited with Prolegomena and Commentary (Oxford)

- (2000) 'The name of Aphrodite', Glotta 76, 134-38

Winkler, J.J. (1990) The Constraints of Desire: The Anthropology of Sex and Gender in Ancient Greece (New York)

Wolanin, H. (1995) 'Plato and the position of etymology in Greek intellectual culture', in W. Smoczynski (ed.), Analecta Indoeuropaea Cracoviensia Ioannis Safarewicz memoriae dicata (Krakow) 513-35

Woodhead, W.D. (1928) Etymologizing in Greek Literature from Homer to Philo Judaeus (Toronto) 